\title{
IDENTIFICATION KEY FOR HOLOCENE LACUSTRINE ARCELLACEAN (THECAMOEBIAN) TAXA
}

\author{
Arun Kumar and Andrew P. Dalby
}

ABSTRACT

Arcellaceans (thecamoebians), predominantly freshwater protozoans, have been studied for over a century. However, in the last ten years their usefulness as paleoenvironmental indicators has become better understood because researchers have recognized that certain morphotypes (strains) prefer distinct microenvironments. Unfortunately, the monoclonal nature and simle morphorphology of the group has led to considerable taxonomic confusion, threatening their utility in paleolimnological research. This key was created to help new researchers studying the group, and to standardize the taxonomy.

Arun Kumar and Andrew P. Dalby, Ottawa-Carleton Geoscience Centre, Department of Earth Sciences, Carleton University, 1125 Colonel By Drive, Ottawa, Ontario, CANADA K1S 5B6

KEY WORDS: thecamoebian(s), arcellacean(s) Holocene, indentification key

Submission: 10 November, 1997

Acceptance: 7 January, 1998

Copyright: Paleontological Society

http://www.uic.edu/orgs/paleo/homepage.html

\section{INTRODUCTION}

Arcellaceans (thecamoebians) are clonal, predominantly freshwater protozoans, although they can also occur in brackish water environments and moist soils (Medioli and Scott 1983). They can be found in a wide range of geographic settings, ranging from tropical to arctic latitudes (Nair and Mukherjee 1968; Green 1975; Dallimore et al. 1997). These organisms have an amoebid sarcodine cell with pseudopods and a simple sac-like test, either flattened or rounded with an aperture located on or near the tapered end, or a beret-shaped test with an invaginated aperture on the ventral side which is more or less flattened. A substantial amount of morphological variability has been observed among these two broad groups.

A few forms like Lagenodifflugia and Pontigulasia appear to have a second chamber consisting of an enlarged collar separated from the rest of the test by a distinct constriction (Medioli and Scott 1988; Medioli et al. 1990). Tests are either secreted (autogenous), or agglutinated (xenogenous) with sand particles or diatom frustules (xenosomes) in autogenous cement. Autogenous tests are usually smooth, proteinaceous, sometimes made of siliceous platelets (idiosomes), or rarely calcareous. (See Medioli et al. 1990, for a review of fossil arcellaceans).

Arcellacean tests do not demonstrate a high degree of morphological diversity, but important taxonomic characteristics include (Asioli et al. 1996): presence or absence of spines; nature and shape of xenosomes and idiosomes; shape and composition of tests; and morphological 
features associated with the apertures, such as diaphragms, collars, lobes, and teeth.

Test size can vary between 50 to 300 um or even greater, thus it is of no taxonomic importance as it is determined at the time of fission by the volume of cytoplasm available in the parent test (Medioli and Scott 1983). Cytoplasmic volume is in turn probably controlled by the availability of food in the period preceeding reproduction (Medioli et al. 1990).

It has long been known that various arcellacean species preferentially inhabit specific environments. Rcent research has determined that some infrasubspecific variants (strains) are particularly sensitive to environmental variations (Asioli et al. 1996; Patterson et al. 1996; Reinhardt et al. 1997). In particular, arcellaceans have proven to be useful tools in assessing remediation rates within industrially polluted settings (Asioli et al. 1996; Patterson et al. 1996; Reinhardt et al. 1997).

Unfortunately, the subtle criteria used to differentiate the rather simple arcellacean morphologies, and confusion over the proliferation of taxonomic names during the last hundred years has limited their utility (Medioli and Scott 1983). In this paper, we present a taxonomic key designed to:

1. illustrate the various morphologies that we find useful in paleolimnological research and;

2. provide an arcellacean identification guide for future researchers engaged in paleolimnological research.

Taxa illustrated in this key are from Crosswise and Peterson lakes, near Cobalt, Ontario; Swan Lake, north of Toronto, Ontario; Lake Erie, Ontario; and Lake Orta, northern Italy. Exact sample locations are provided with individual illustrations. 


\section{Key Position: 1}

1a. Test circular, hemispherical to ovoid; made of proteinaceous matter and agglutinated grains.

1b. Test ovoid, pyriform, elongate to acuminate; made of agglutinated mineral grains or diatom frustules.

\section{Proceed to 2}

Proceed to 7 


\section{Key Position: 2}

2 a. Test circular in dorso-ventral view, planoconvex to hemispherical in lateral view, made of proteinaceous matter, surface smooth or punctate; aperture central, large and circular.

\section{SEE Figure 2-1}

\section{Back to (1a)}

2 b. Test with or without spines, agglutinated with mineral grains, aperture sub-terminal or occasionally central, circular or oval, invaginated.

\section{FIGURE 2-1}

\section{Arcella vulgaris Ehrenberg 1830}

Arcella vulgaris EHRENBERG 1830, p. 40, pl. 1, fig. 6

Arcella vulgaris Ehrenberg REINHARDT et al. 1997, pl. 1, fig. 3

Remarks: Distinguished from Centropyxis aculeata "discoides" by having no agglutinated particles whatsoever, thus the test is hyaline and transparent. Specimen from Crosswise Lake, near Cobalt, Ontario.

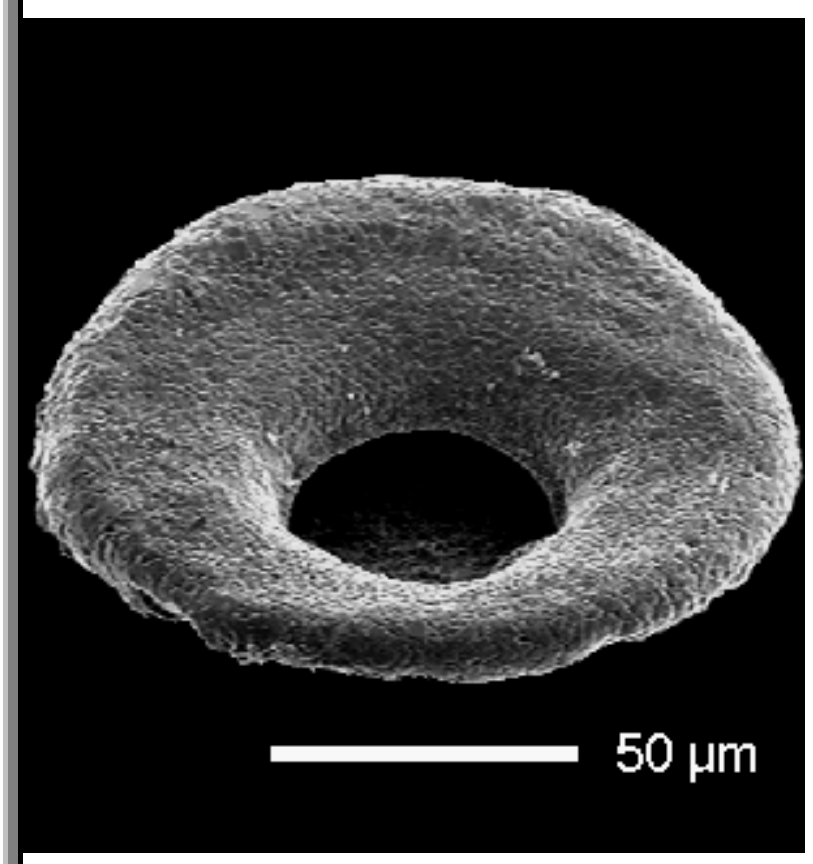




\begin{tabular}{|c|c|}
\hline Key Position: 3 & Back to (2b) \\
\hline $\begin{array}{l}\text { 3a. Test ventrally depressed, almost } \\
\text { circular dorso-ventrally, anterior angle } \\
\text { varies between } 15-40 \text { degrees, posterior } \\
\text { slope ill-defined or practically absent. } \\
\text { Height/length ratio is low }(0.4-0.5) \text {. }\end{array}$ & $\begin{array}{l}\text { 3b. Test less depressed on ventral side } \\
\text { than in } 3 \text { a, elliptical in dorsal view. } \\
\text { Anterior angle varies between } 45-60 \\
\text { degrees and posterior angle well defined. } \\
\text { Height/length ratio high }(0.5-1.1) \text {. }\end{array}$ \\
\hline Proceed to 4 & Proceed to 5 \\
\hline
\end{tabular}




\begin{tabular}{|c|c|}
\hline Key Position: 4 & Back to (3a) \\
\hline $\begin{array}{l}4 \text { a. Test with } 1 \text { to } 8 \text { spines on postero- } \\
\text { lateral margin. } \\
\text { SEE Figure } 4 \text {-1 }\end{array}$ & $\begin{array}{l}4 \text { b. Test "doughnut" shaped, without } \\
\text { spines. } \\
\text { SEE Figure } \mathbf{4}-\mathbf{2}\end{array}$ \\
\hline $\begin{array}{l}\text { FIGURE } 4 \text {-1 } \\
\text { Centropyxis aculeata Ehrenberg } 1832 \\
\text { "aculeata" } \\
\text { Arcella aculeata EHRENBERG 1832, p. } 91 \\
\text { Arcella aculeata "aculeata" REINHARDT et } \\
\text { al. 1997, pl. 1, fig. } 1 \\
\text { Remarks: Distinguished from Centropyxis } \\
\text { aculeata "discoides" by having spines. It } \\
\text { should be noted that on some specimens } \\
\text { these spines have broken off, but the stubs } \\
\text { at the bases of the spines remain. } \\
\text { Specimen from Crosswise Lake, near } \\
\text { Cobalt, Ontario. }\end{array}$ & $\begin{array}{l}\text { FIGURE } 4 \text {-2 } \\
\text { Centropyxis aculeata Ehrenberg } 1832 \\
\text { "discoides" } \\
\text { Arcella discoides EHRENBERG 1843, p. } \\
139 \\
\text { Arcella discoides Ehrenberg, } \\
\text { EHRENBERG 1872, p. 259, pl. 3, fig. } 1 \\
\text { Arcella discoides Ehrenberg, LEIDY 1879, } \\
\text { p. 173, pl. 28, figs. 14-38 } \\
\text { Centropyxis aculeata var.discoides } \\
\text { PENARD 1890, p. 150, pl. 5, figs. 38-41 } \\
\text { Centropyxis discoides Penard [sic], } \\
\text { OGDEN and HEDLEY 1980, p. 54, pl. 16, } \\
\text { figs. a-e } \\
\text { Centropyxis aculeata "discoides" } \\
\text { REINHARDT et al. 1997, pl. 1, fig. } 2 \\
\text { Specimen from Crosswise Lake, near } \\
\text { Cobalt, Ontario. }\end{array}$ \\
\hline
\end{tabular}




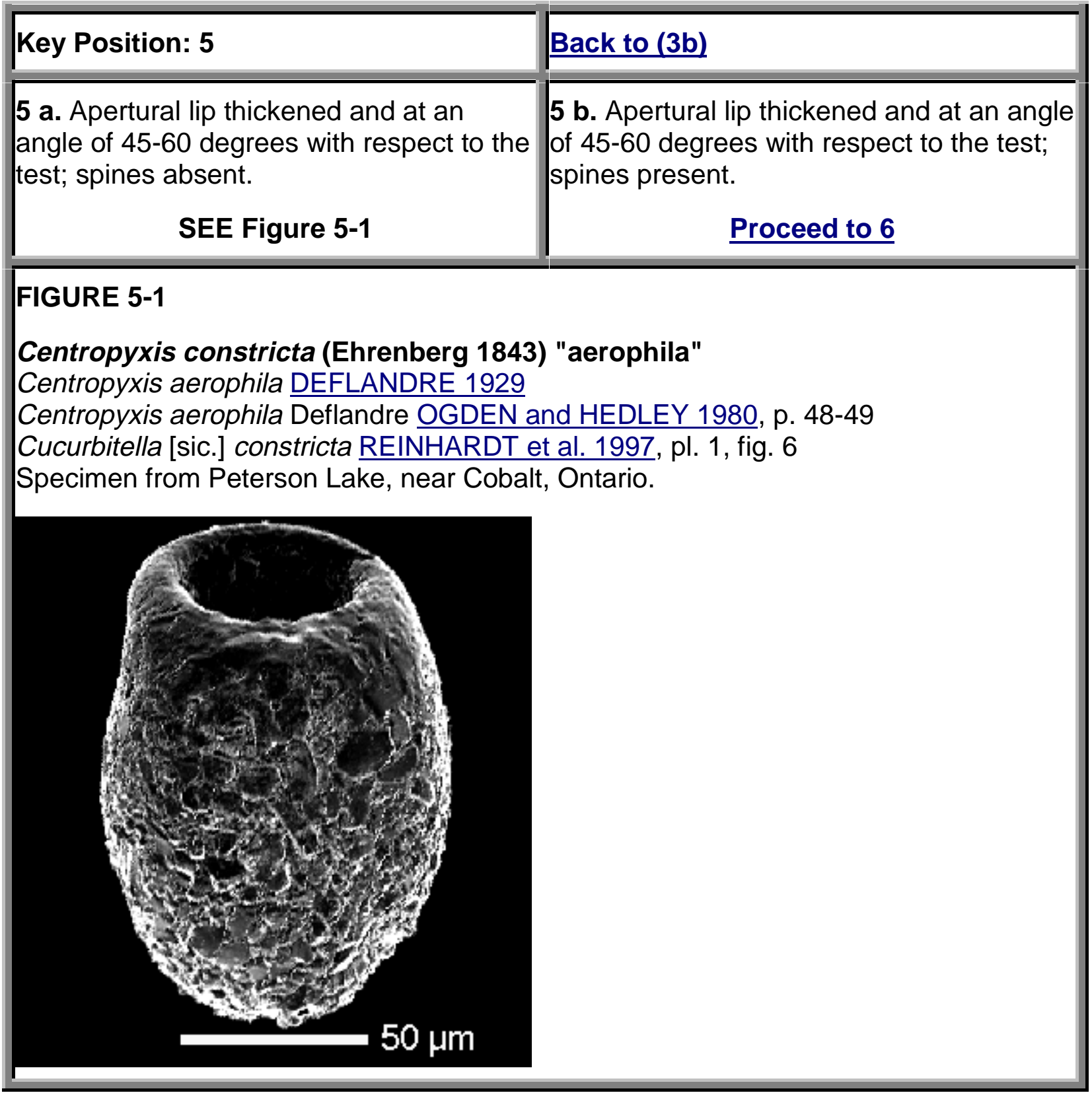




\begin{tabular}{|c|c|}
\hline Key Position: 6 & Back to (5b) \\
\hline $\begin{array}{l}6 \text { a. Test less flattened than } 6 \mathrm{~b} \text { with } \\
\text { generally } 3 \text { or less spines on fundus, but } \\
\text { may have more. } \\
\text { SEE Figure } 6-1\end{array}$ & $\begin{array}{l}6 \text { b. Test more flattened than } 6 \text { a with } 4 \text { or } \\
\text { more spines on fundus. } \\
\text { SEE Figure } 6 \text {-2 }\end{array}$ \\
\hline $\begin{array}{l}\text { FIGURE } 6 \text {-1 } \\
\text { Centropyxis constricta (Ehrenberg } \\
\text { 1843) "constricta" } \\
\text { Arcella constricta EHRENBERG 1843, p. } \\
\text { 410, pl. 4, fig. 35, pl. 5, fig. } 1 \\
\text { Centropyxis constricta "constricta" } \\
\text { REINHARDT et al. 1997, pl. 1, fig. } 4 \\
\text { Specimen from Crosswise Lake, near } \\
\text { Cobalt, Ontario. }\end{array}$ & $\begin{array}{l}\text { FIGURE } 6 \text {-2 } \\
\text { Centropyxis constricta (Ehrenberg } \\
\text { 1843) "spinosa" } \\
\text { Centropyxis spinosa CASH in CASH and } \\
\text { HOPKINSON 1905, p. 135, text figs. } 26 \text { a- } \\
\text { C, pl. 16, fig. } 15 \\
\text { Centropyxis spinosa Cash, OGDEN and } \\
\text { HEDLEY 1980, p. 62, pl. 20, figs. a-d } \\
\text { Centropyxis constricta "spinosa" } \\
\text { REINHARDT et al. 1997, pl. 1, fig. } 5 \\
\text { Specimen from Peterson Lake, near } \\
\text { Cobalt, Ontario. }\end{array}$ \\
\hline
\end{tabular}




\begin{tabular}{|l|l|}
\hline Key Position: 7 & Back to (1b) \\
\hline $\begin{array}{l}\text { 7 a. Test globular and somewhat laterally } \\
\text { compressed; aperture terminal, oval, linear or } \\
\text { circular. }\end{array}$ & $\begin{array}{l}7 \text { b. Test pyriform, acuminate or } \\
\text { ovoid, aperture terminal, circular or } \\
\text { lobed. } \\
\text { Proceed to 8 }\end{array}$ \\
\hline
\end{tabular}




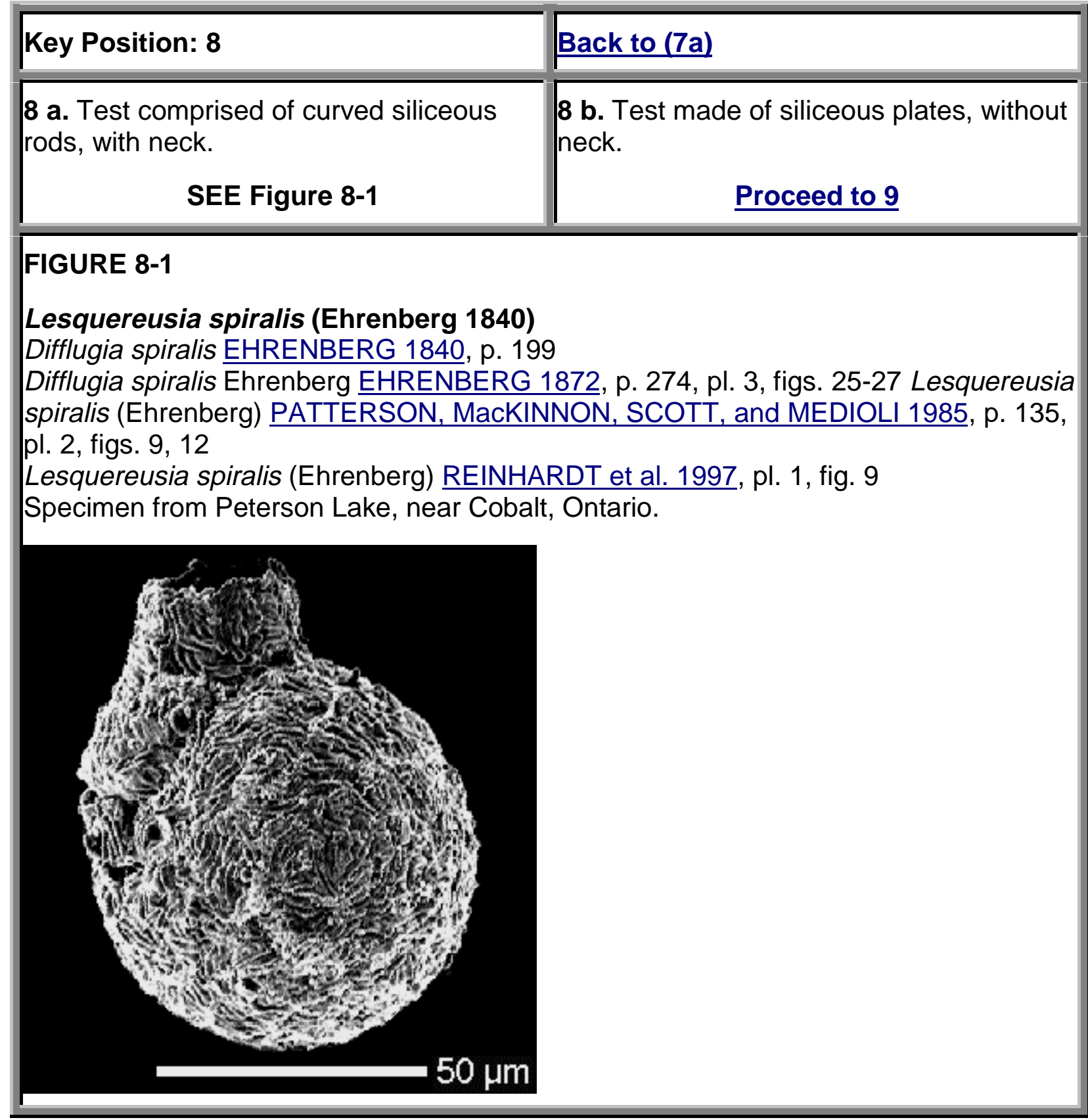




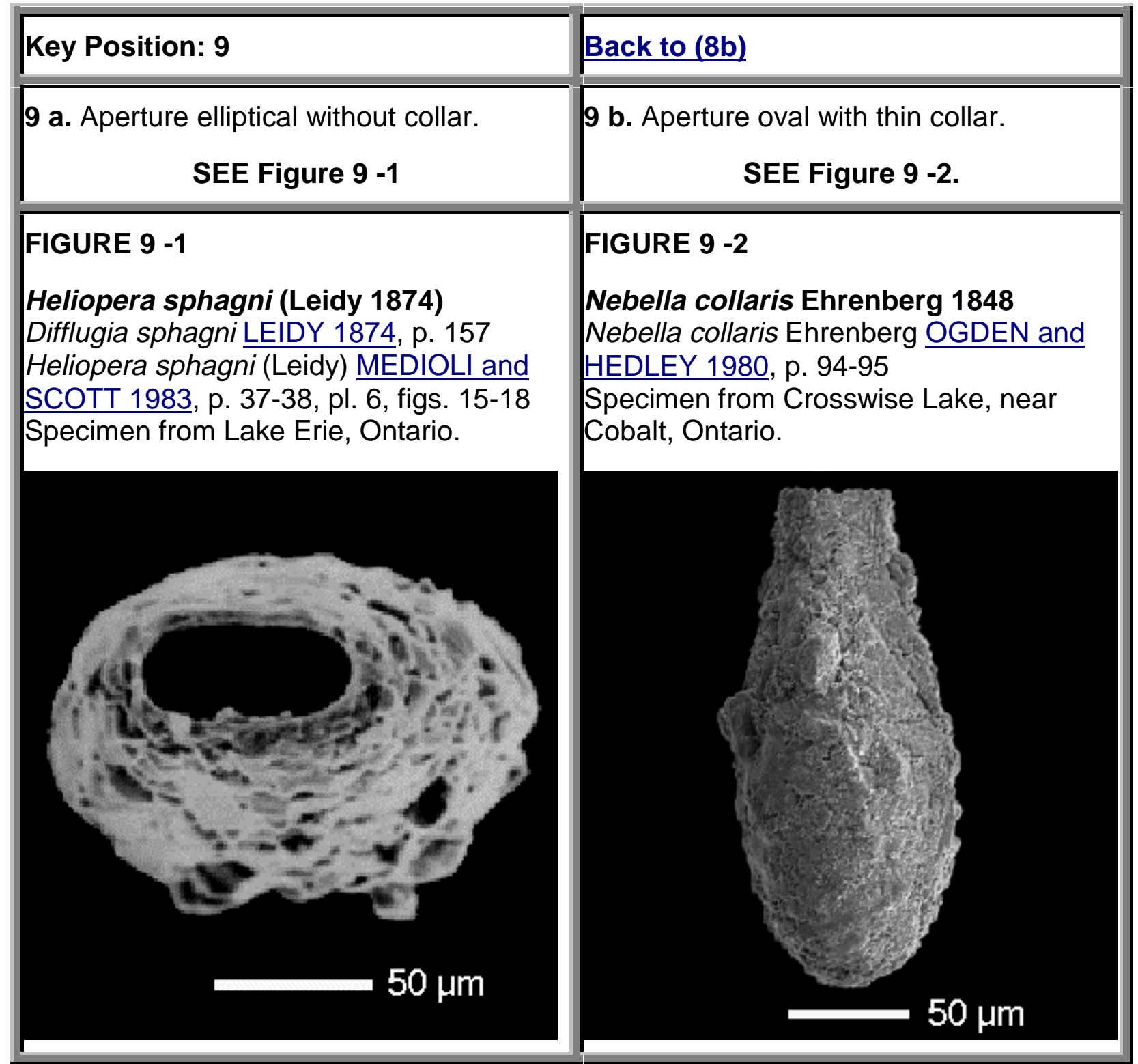




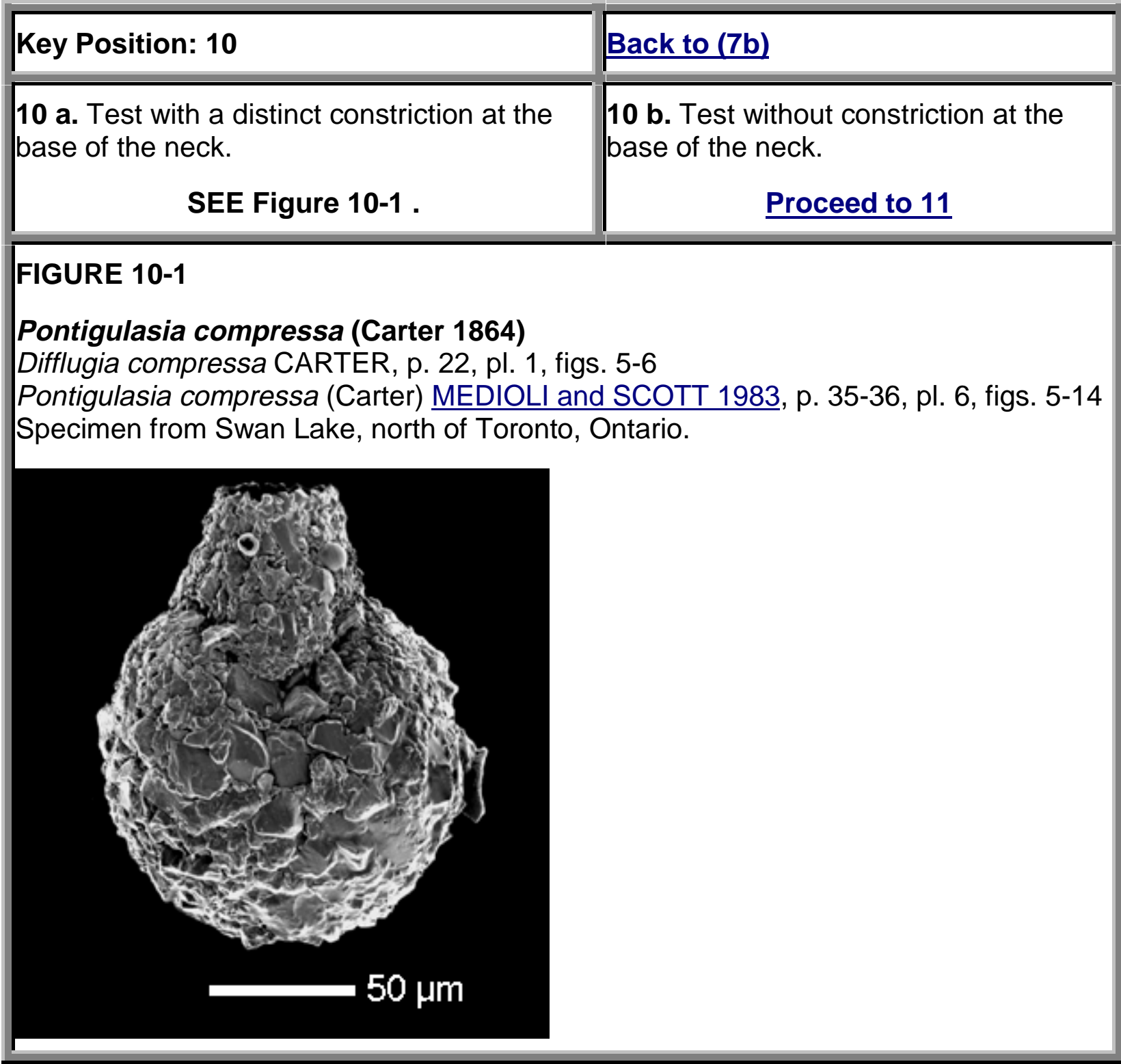




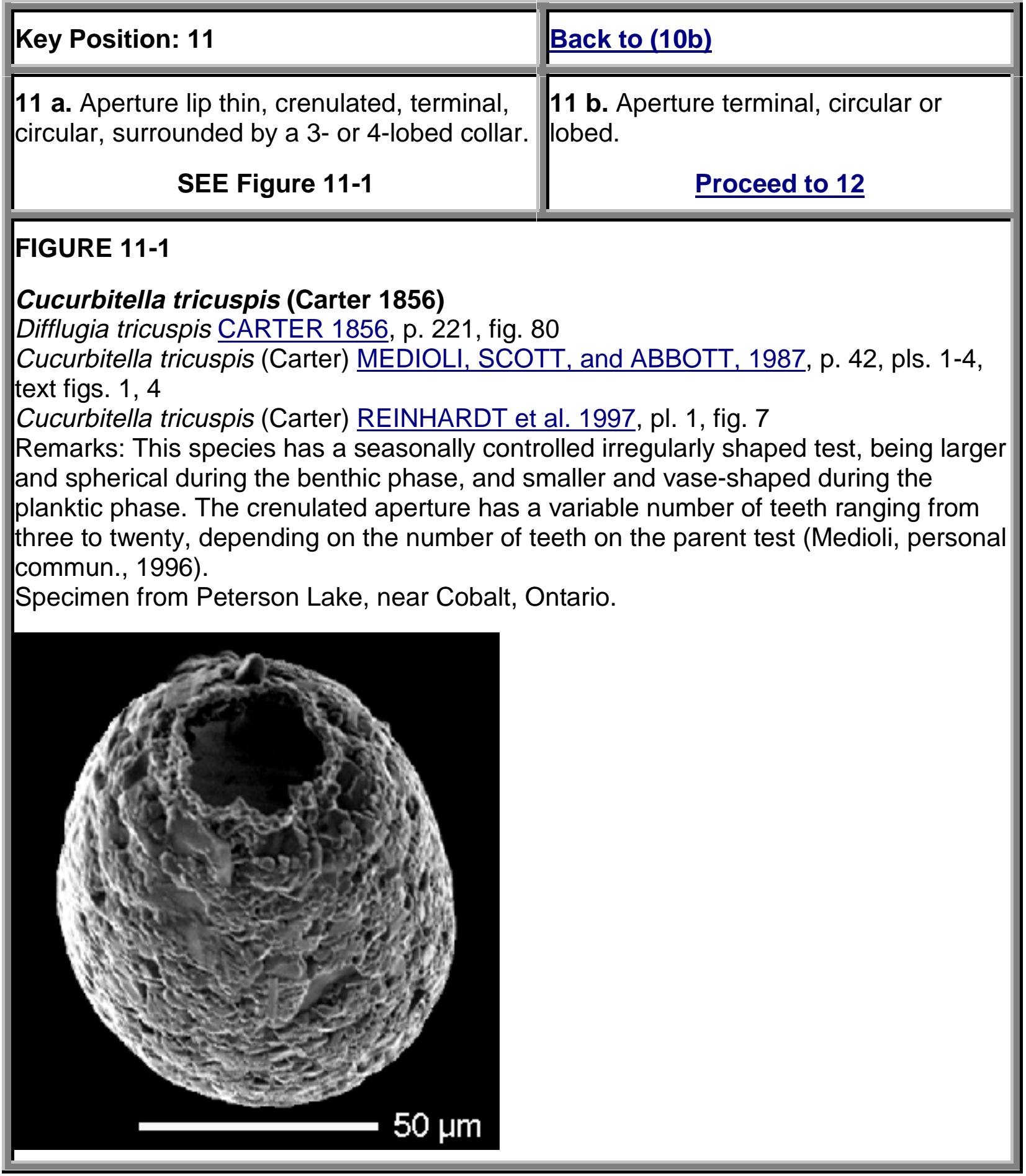




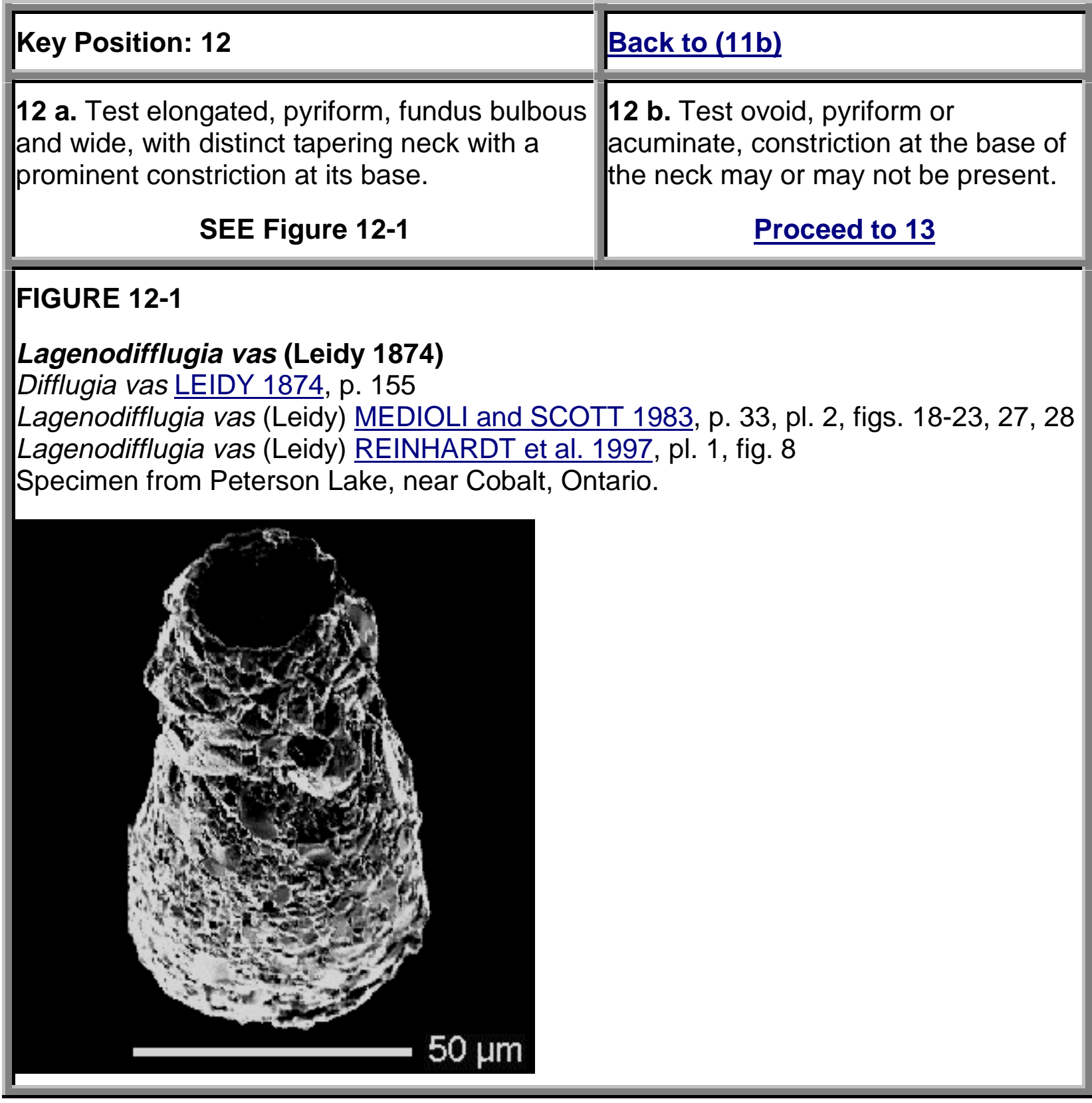




\begin{tabular}{|l|l|}
\hline Key Position: 13 & Back to (12b) \\
\hline $\begin{array}{c}13 \text { a. Test elongated, fundus tapering, } \\
\text { acuminate with one or more spines. } \\
\text { Proceed to } 14\end{array}$ & $\begin{array}{l}13 \mathrm{~b} \text {. Test subspherical, ovoidal with } \\
\text { or without spines. } \\
\text { Proceed to 16 }\end{array}$ \\
\hline
\end{tabular}




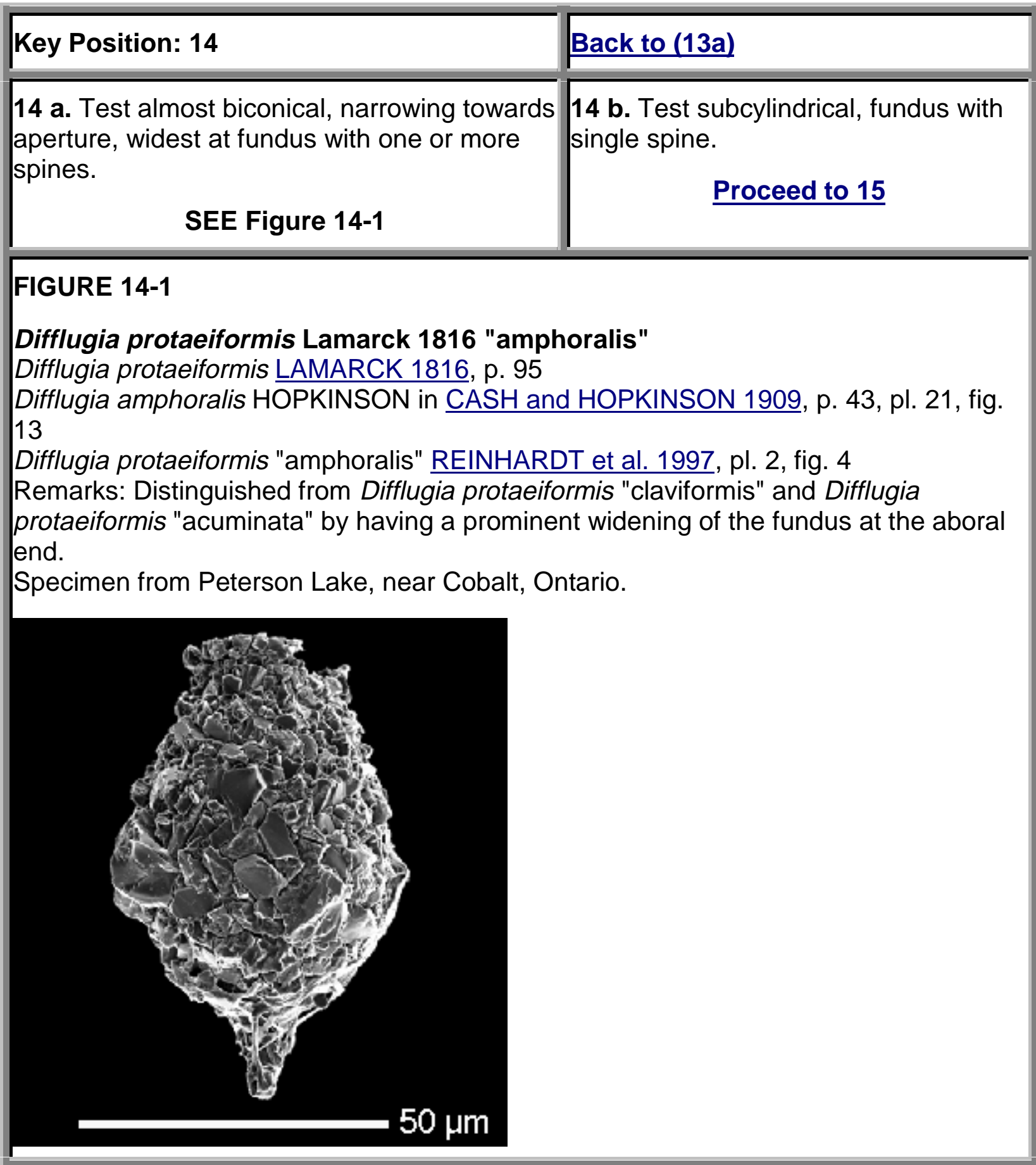




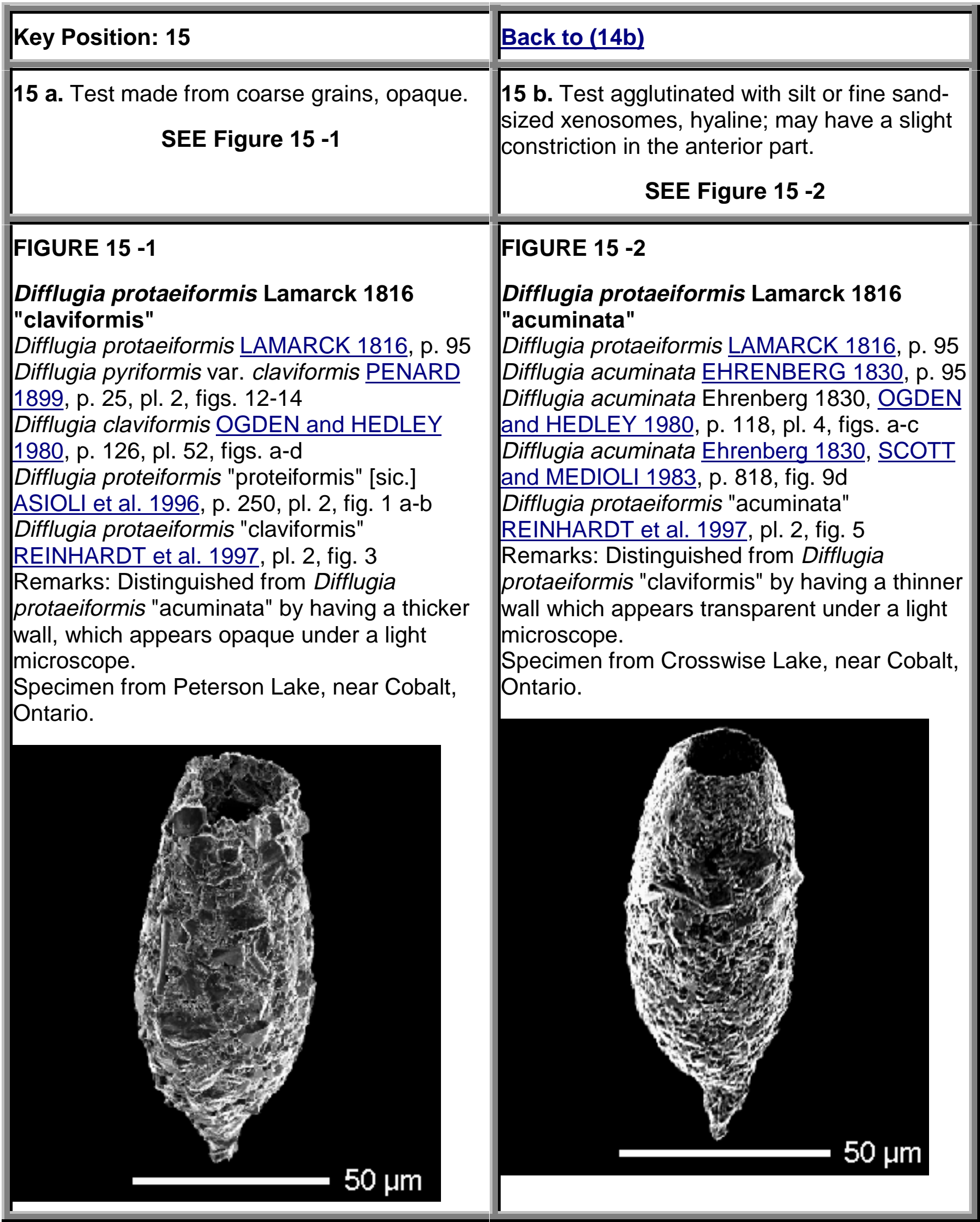




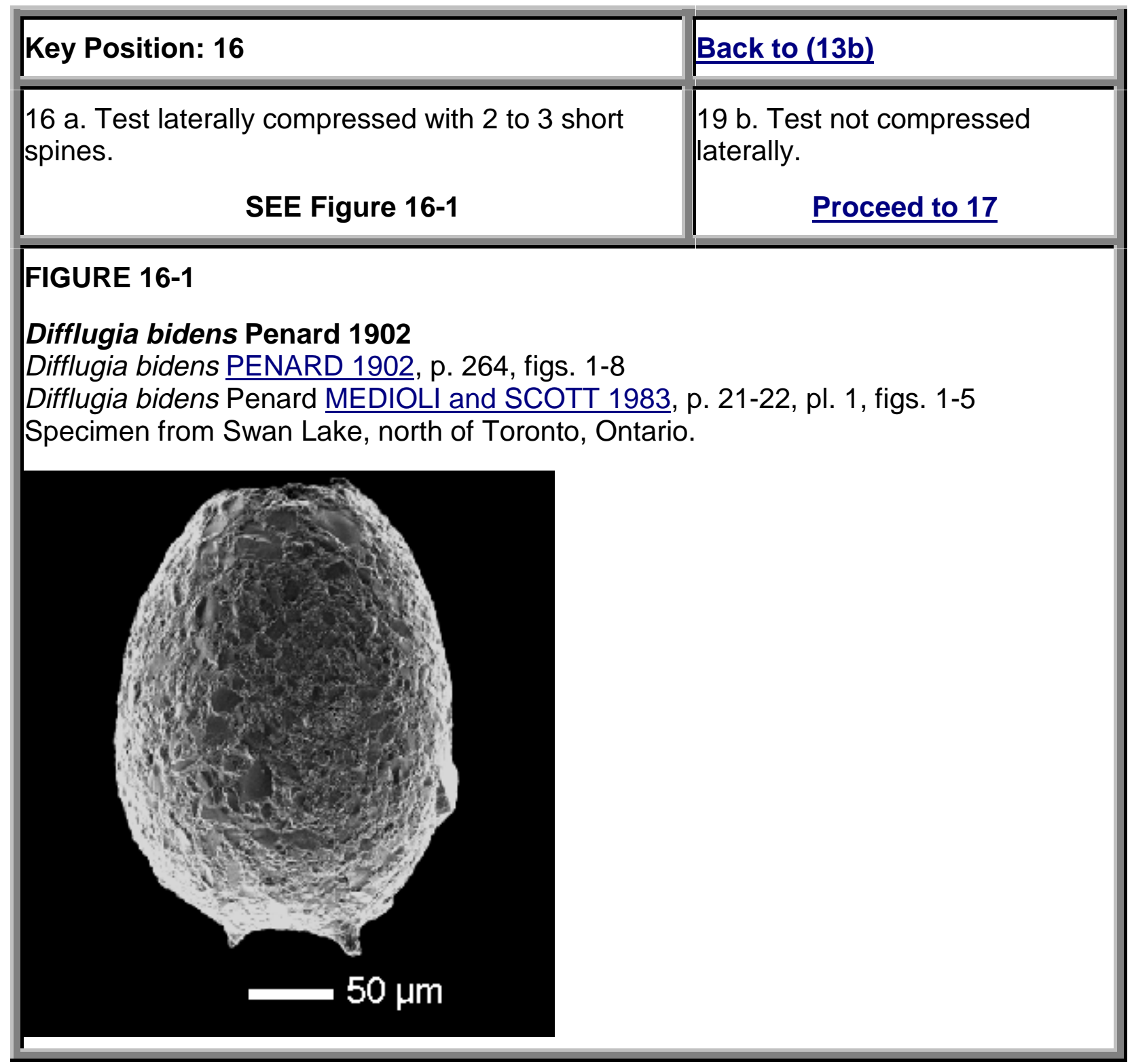




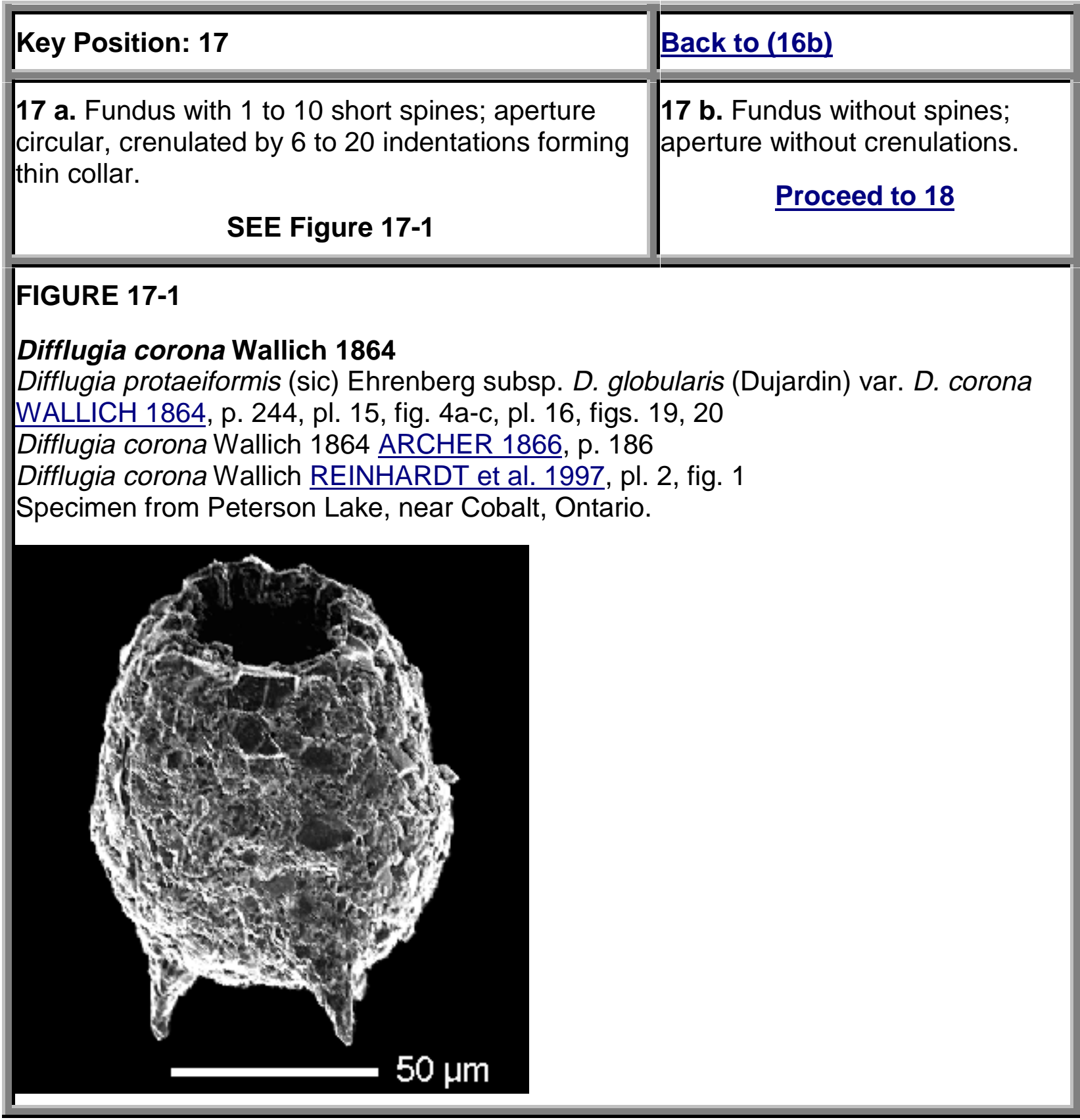




\section{Key Position: 18}

Back to (17b)

18 a. Test with 1 to 8 large ribs running from middle of the test to the fundus and may extend to form blunt spines or tubercles.

18 b. Test without large ribs.

\section{SEE Figure 18-1}

\section{Proceed to 19}

\section{FIGURE 18-1}

Difflugia fragosa Hempel 1898

Difflugia fragosa HEMPEL 1898 , p. 320, figs. 1-2

Difflugia fragosa Hempel MEDIOLI and SCOTT 1983, p. 22-24, pl. 1, figs. 21-27 Specimen from Lake Erie, Ontario.

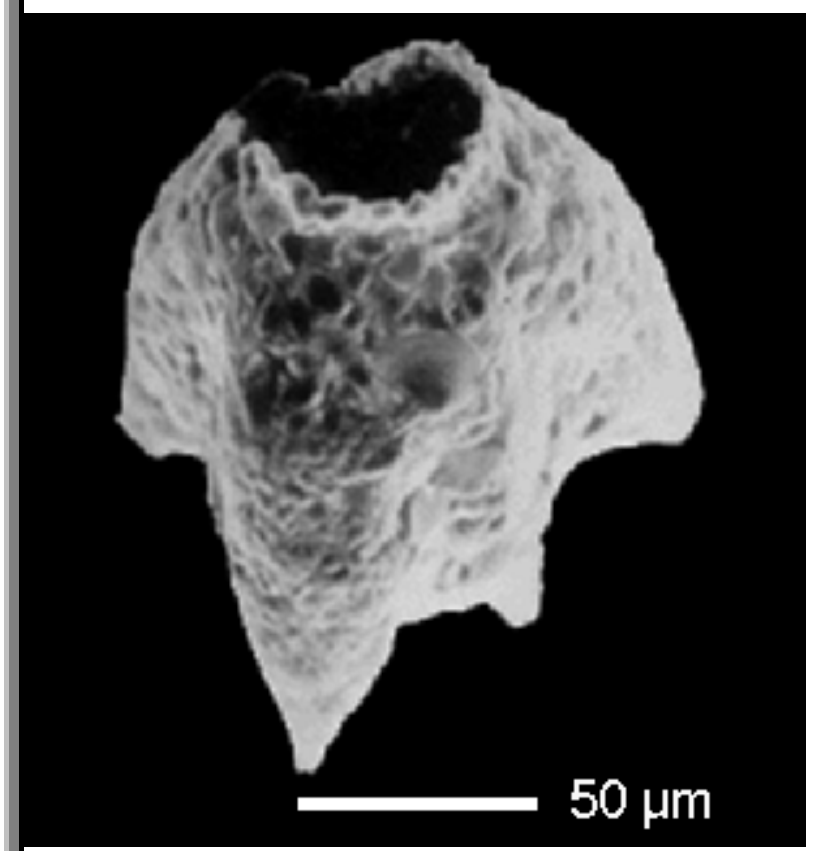




\begin{tabular}{|l|l|}
\hline Key Position: 19 & Back to (18b) \\
\hline \begin{tabular}{l|l}
19 a. Test amphora- or cauldron- \\
shaped, aperture circular with distinct \\
collar.
\end{tabular} & $\begin{array}{l}19 \mathrm{~b} \text {. Test flask-shaped, sphaeroidal to } \\
\text { ellipsoidal, aperture circular to subcircular } \\
\text { without collar. }\end{array}$ \\
\hline \multicolumn{1}{|c|}{ Proceed to 20} & Proceed to 23 \\
\hline
\end{tabular}




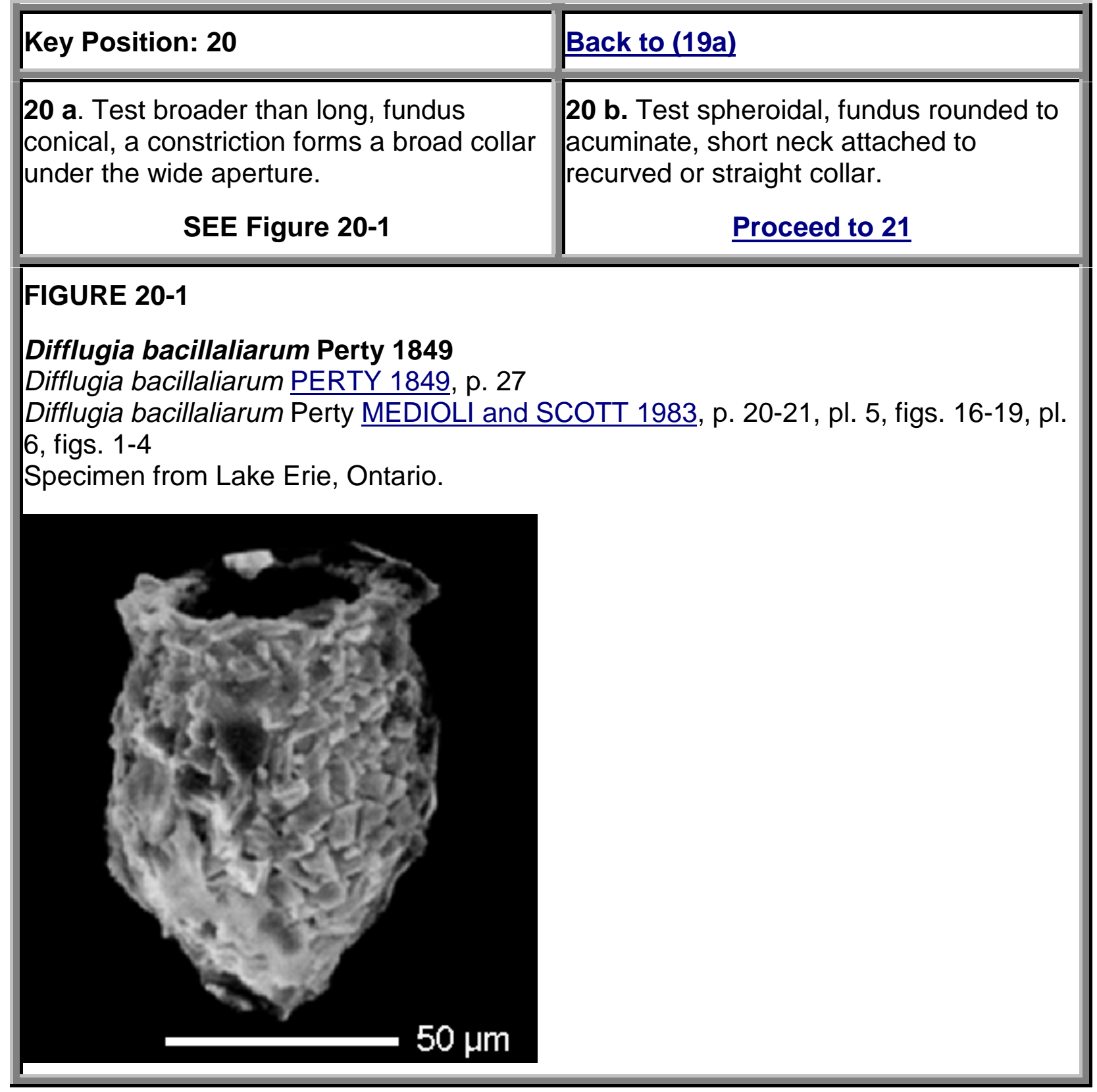




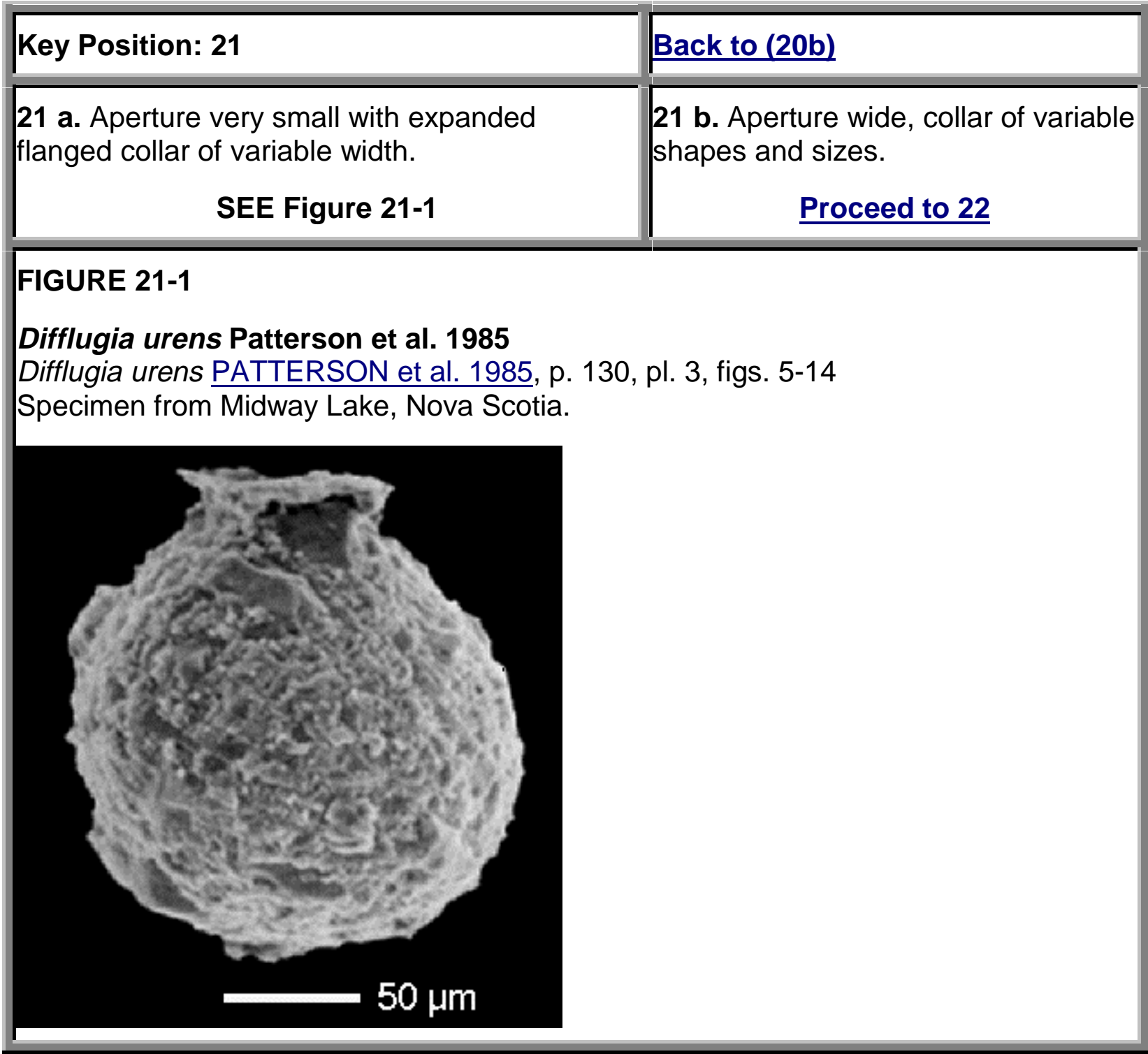




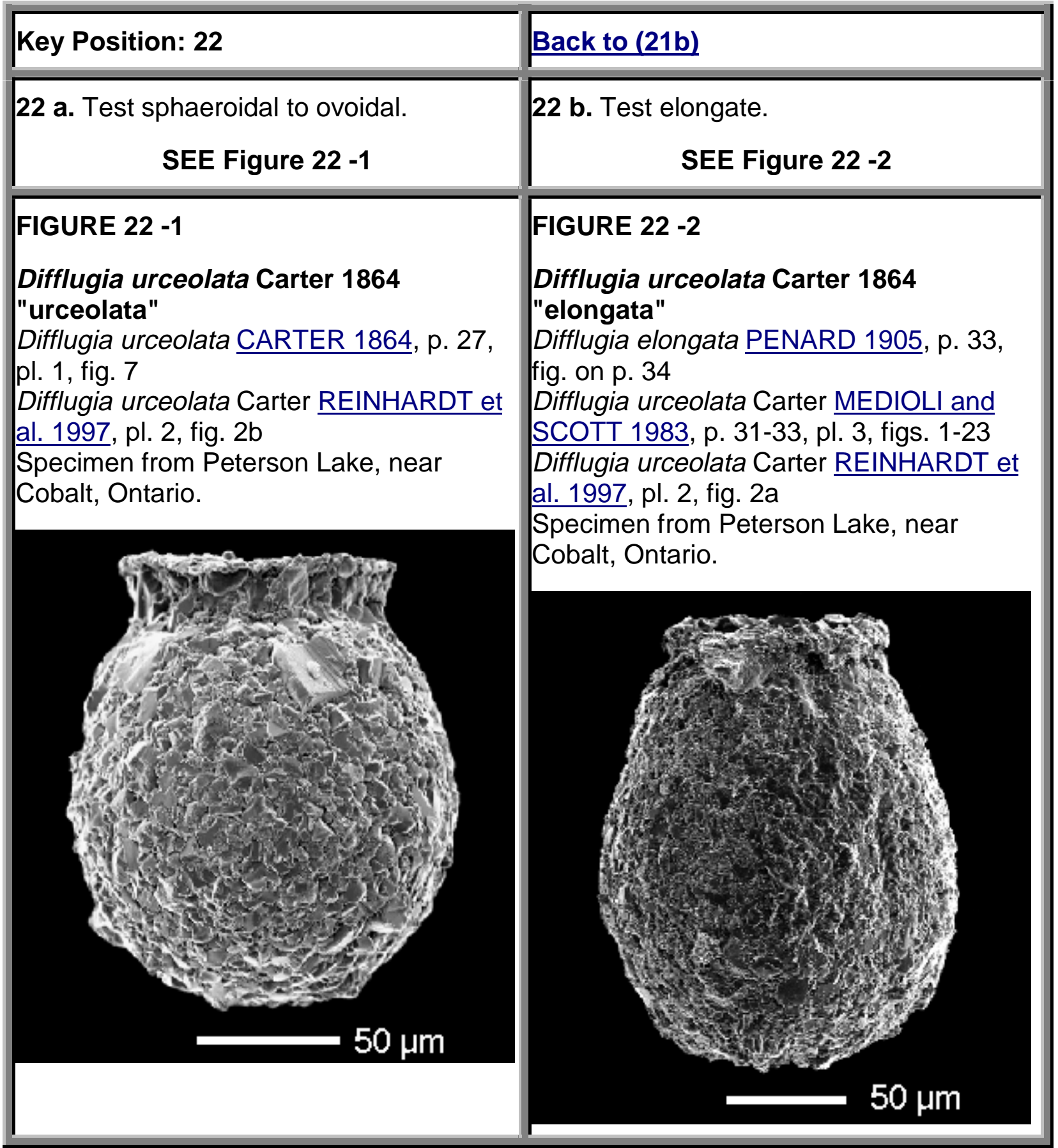




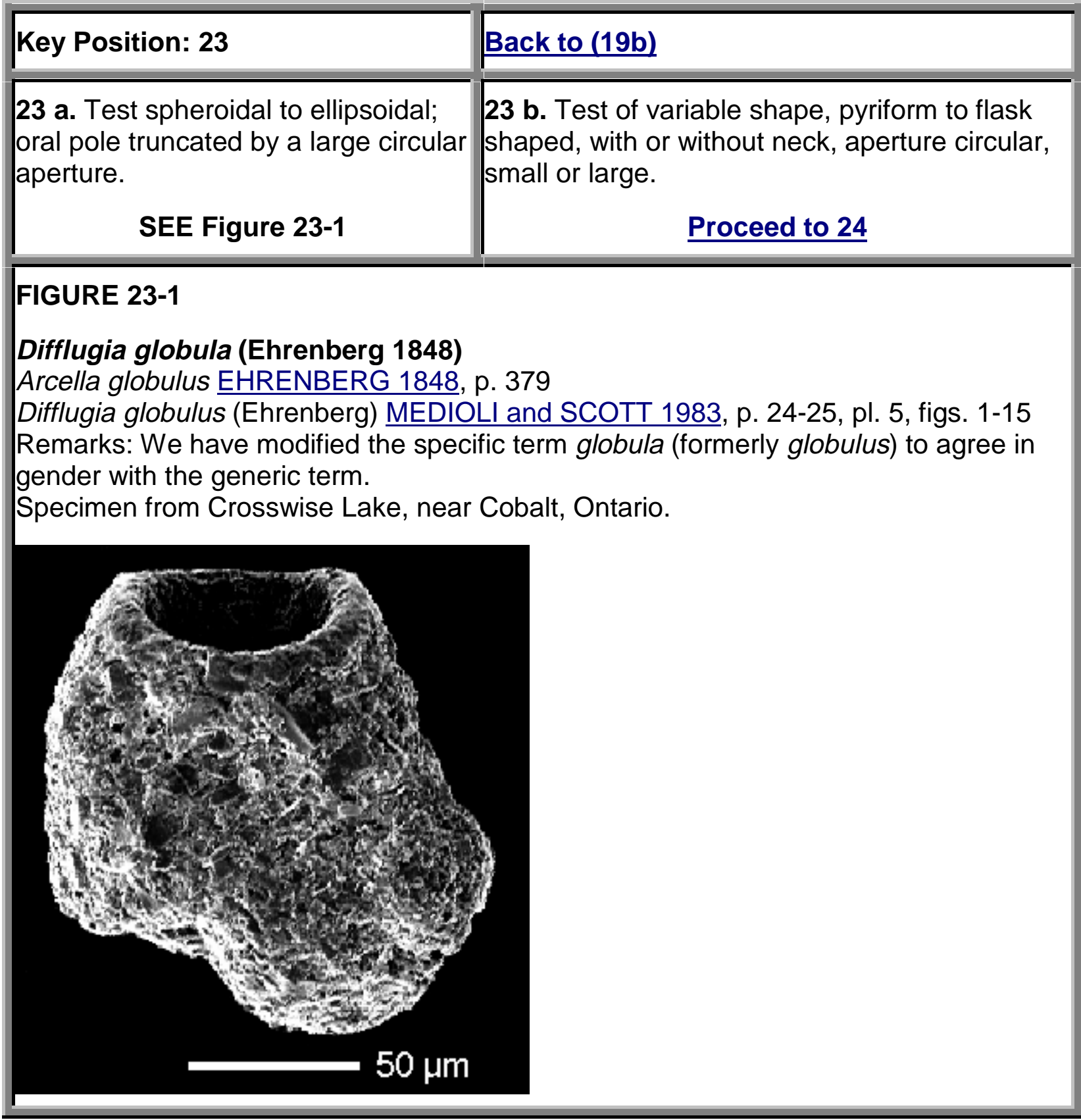




Key Position: 24

24 a. Test ovoid with rounded fundus, aperture large and circular.

\section{SEE Figure 24-1}

\section{Back to (23b)}

24 b. Test elongate, flask-shaped, aperture circular, large or small.

\section{Proceed to 25}

\section{FIGURE 24-1}

Difflugia oblonga Ehrenberg 1832 "glans"

Difflugia glans PENARD 1902

Difflugia oblonga "glans" REINHARDT et al. 1997, pl. 2, fig. 7

Specimen from Crosswise Lake, near Cobalt, Ontario.

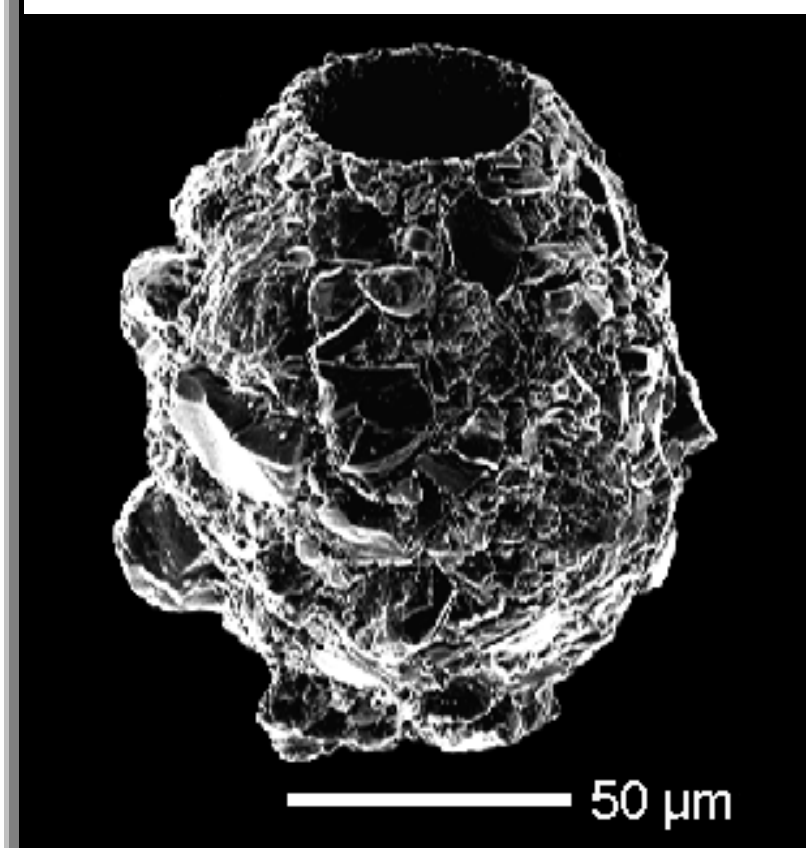




\begin{tabular}{|l|c|}
\hline Key Position: 25 & Back to (24b) \\
\hline $\begin{array}{c}25 \text { a. Aperture with crenulations. } \\
\text { Proceed to } 26\end{array}$ & 25 b. Aperture without crenulations. \\
\hline
\end{tabular}




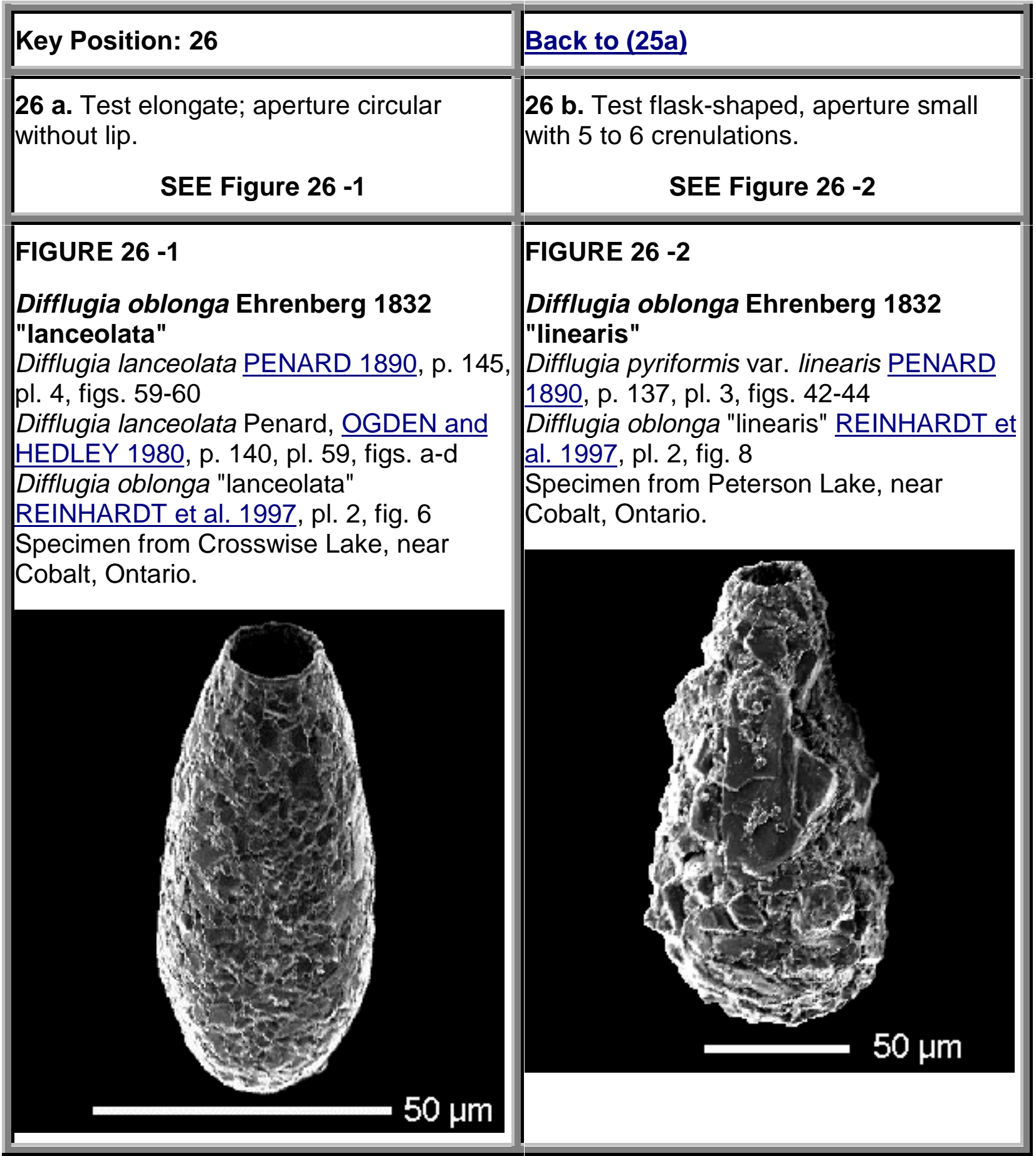


27 a. Test flask-shaped with a spine on fundus.

27 b. Test flask-shaped without spine on fundus.

\section{SEE Figure 27-1}

\section{Proceed to 28}

\section{FIGURE 27-1}

Difflugia oblonga Ehrenberg 1832 "spinosa"

Difflugia oblonga "spinosa" REINHARDT et al. 1997, pl. 2, fig. 11

Specimen from Crosswise Lake, near Cobalt, Ontario.

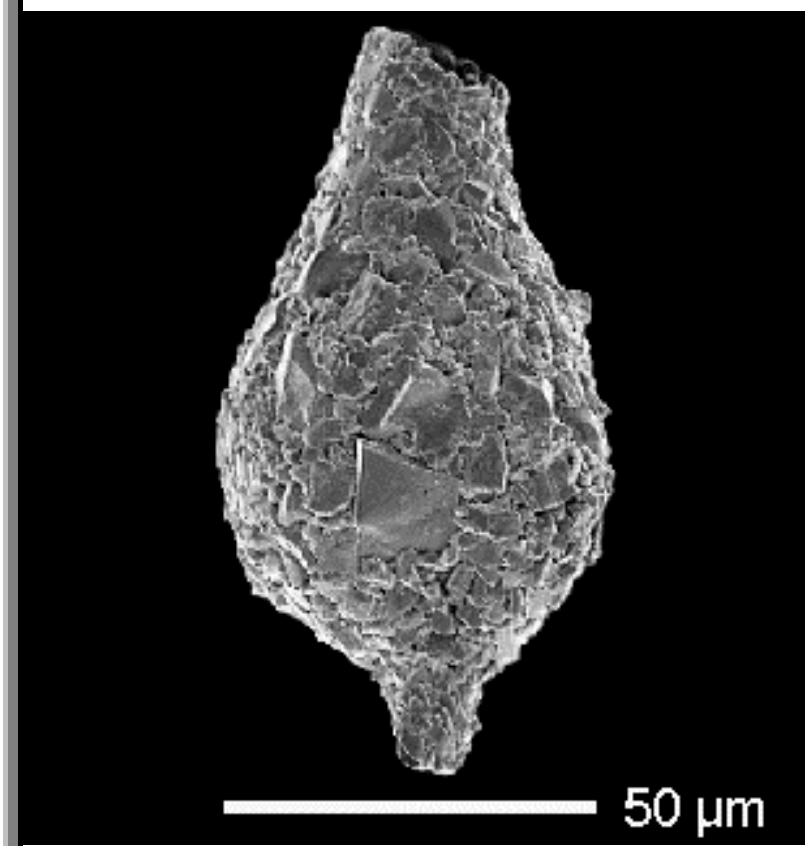




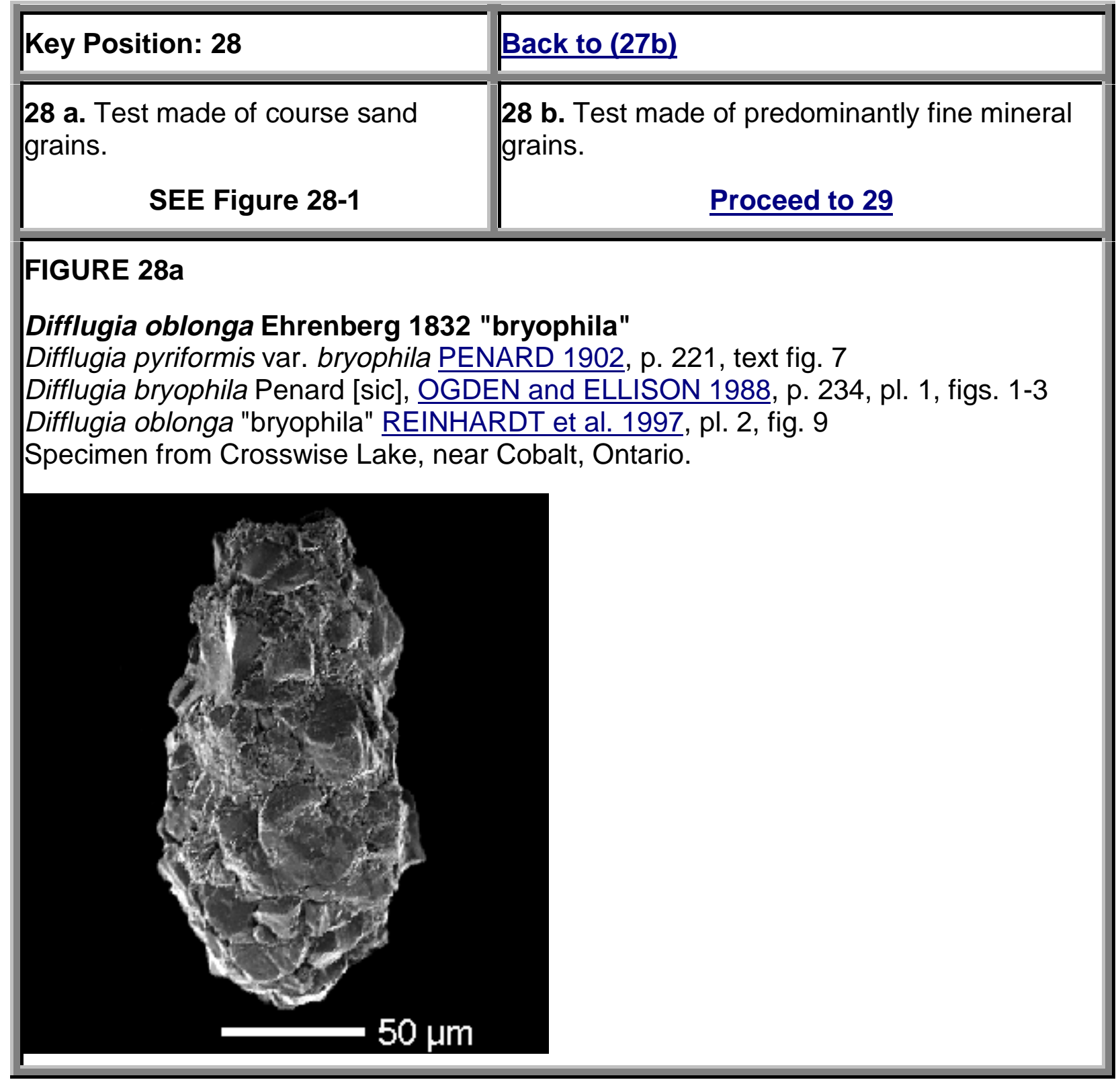




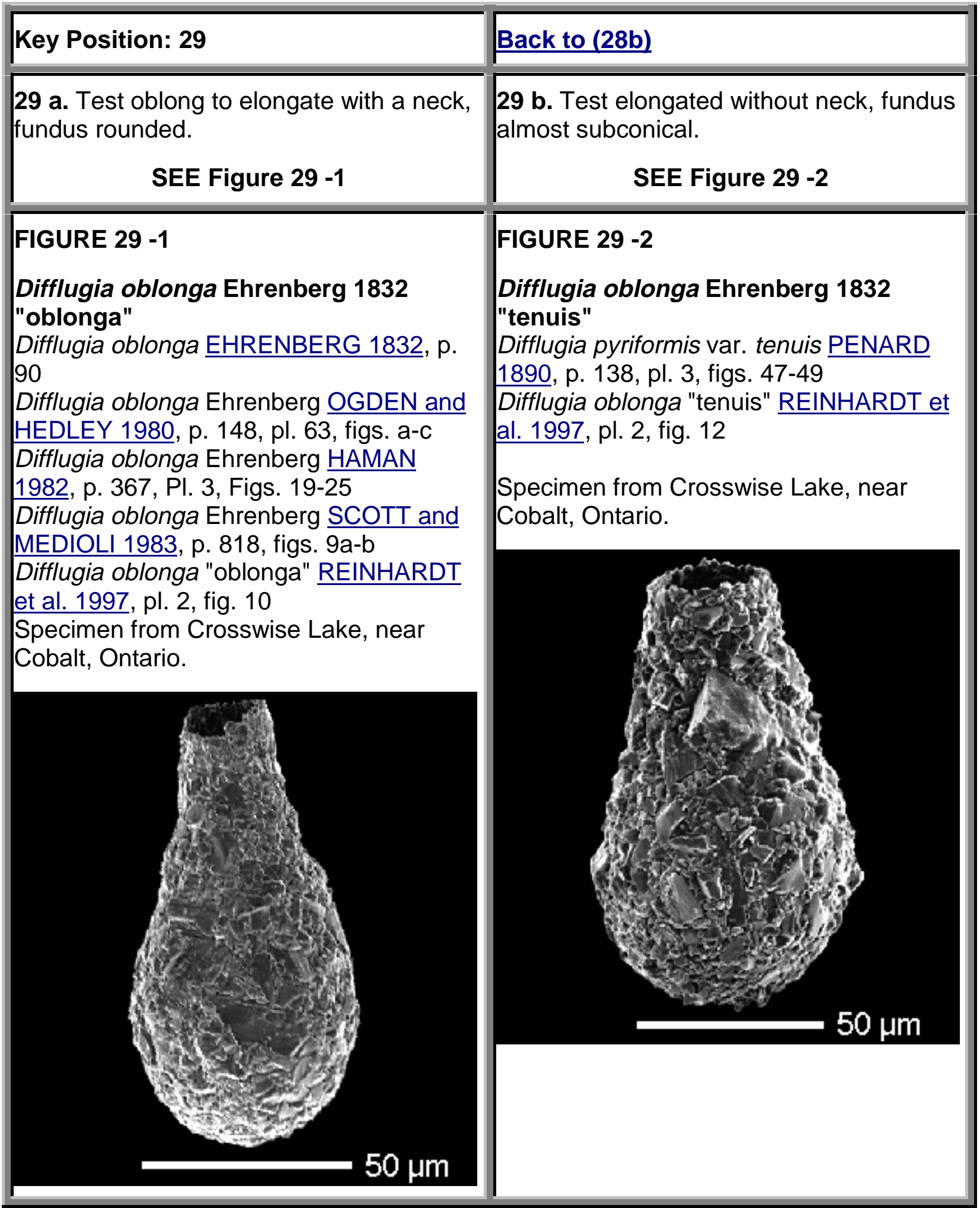




\section{REFERENCES}

Archer, W. 1866. Quarterly Journal of Microscopical Science, new series, 6:185-188.

Asioli, A., Medioli, F.S., and Patterson, R.T. 1996. Thecamoebians as a tool for reconstruction of paleoenvironments in some Italian lakes in the foothills of the southern Alps (Orta, Varese and Candia). Journal of Foraminiferal Research, 26:248-263.

Carter, H.J. 1856. Notes on the freshwater Infusoria of the island of Bombay. No. 1. Organization. Annals and Magazine of Natural History, series. 2, 18(105):221-249.

Carter, H.J. 1864. On freshwater Rhizopoda of England and India. Annals and Magazine of Natural History, series 3, 13:18-39.

Cash, J., and Hopkinson, J. 1905. The British freshwater Rhizopoda and Heliozoa. Vol. I: Rhizopoda, part 1. Ray Society, London.

Cash, J., and Hopkinson, J. 1909. The British freshwater Rhizopoda and Heliozoa. Vol. II: Rhizopoda, part 2. Ray Society, London.

Dallimore, A., Schršder-Adams, C.J., and Burn, C.R. 1997. Environmental control on thecamoebian assemblages in lakes on Richards Island, MacKenzie Delta, N.W.T. Geological Association of CanadaMineralogical Association of Canada Annual Meeting May 19-21, 1997, Abstract Volume, A34

Deflandre, G. 1929. Le genre centropyxis Stein. Archiv fur Protistenkunde, 67:323-375.

Ehrenberg, C.G. 1830. Organisation, systematik und geographisches VerhŠltnis der Infusionsthierchen. Druckerei der Kšnigliche Akademie der Wissenschaften, Berlin.

Ehrenberg, C.G. 1832. †ber die Entwicklung und Lebensdauer der Infusionsthiere, nebst ferneren BeitrŠgen zu einer Vergleichung ihrer organischen Systeme. Kšnigliche Akademie der Wissenschaften zu Berlin Physikalische Abhandlungen, 1831, 1-154.

Ehrenberg, C.G. 1840. Das gršssere Infusorienwerke. Kšnigliche Preussischen Akademie der Wissenschaften zu Berlin Bericht, 198-219.

Ehrenberg, C.G. 1843. Verbreitung und Einfluss des mikroskopischen Lebens in SŸd-und Nord Amerika.

Kšnigliche Akademie der Wissenschaften zu Berlin Physikalische Abhandlungen, 1841, 291-446.

Ehrenberg, C.G. 1848. Fortgesetzte Beobachtungen uber jetzt herrschende atmospharische mikroskopische Verhaltnisse. Bericht uber die zur Bekanntmachung geeigneten Verhandlungen der Koniglichen Preussischen Akademie der Wissenschaften zu Berlin, 13:370-381.

Ehrenberg, C.G. 1872. Nachthrag zur †bersicht der organischen AtmosphŠrilien. Kšnigliche Akademie der Wissenschaften zu Berlin Physikalische Abhandlungen, 1871, 233-275.

Green, J. 1975. Freshwater ecology in the Mato Grosso, Central Brazil, IV: Associations of testate Rhizopoda. Journal of Natural History, 9:545-560.

Haman, D. 1982. Modern Thecamoebinids (Arcellinida) from the Balize Delta, Louisiana. Transactions of the Gulf Coast Association of Geological Societies, 32:353-376.

Hempel, A. 1898. A list of the Protozoa and Rotifera found in the Illinois River and adjacent lakes at Havana, III. Illinois State Laboratory of Natural History Bulletin, 5:301-388.

Lamarck, J.B. 1816. Histoire naturelle des animaux sans vertebres. Verdiere, Paris, 2:1-568.

Leidy, J. 1874. Notice of some new fresh-water rhizopods. Proceedings of the Academy of Natural Sciences 
of Philadelphia, series 3:77-79.

Leidy, J. 1879. Fresh water rhizopods of North America. United States Geological Survey of the Territories Report, 12:1-324.

Medioli, F.S., Scott, D.B., and Abbott, B.H. 1987. A case study of protozoan interclonal variability: taxonomic implications. Journal of Foraminiferal Research, 17:28-47.

Medioli, F.S., and Scott, D.B. 1983. Holocene Arcellacea (Thecamoebians) from eastern Canada. Cushman Foundation For Foraminiferal Research Special Publication 21.

Medioli, F.S., and Scott, D.B. 1988. Lacustrine thecamoebians (mainly arcellaceans) as potential tools for paleolimnological interpretations. Paleogeography, Paleoclimatology, Paleoecology, 62:361-386.

Medioli, F.S., Scott, D.B., Collins, E.S., and McCarthy, F.M.G. 1990. Fossil thecamoebians: present status and prospects for the future. In Hemleben, C., Kaminski, M.A., Kuhnt, W. and Scott, D.B., (eds.), Paleoecology, Biostratigraphy, Paleoceanography and Taxonomy of Agglutinated Foraminifera, North Atlantic Treaty Organization Advanced Study Institute Series, Series C. Mathematical and Physical Sciences, 327:813840.

Nair, K.N., and Mukherjee, R.N. 1968. On some testacean rhizopods (Protozoa: Sarcodina) of the ground and tree mosses from Calcutta and its environs. Proceedings of the National Academy of Sciences of India, 38B:185-193.

Ogden, C.G., and Ellison, R.L. 1988. The value of the organic cement matrix in the identification of the shells of fossil testate amoeba. Journal of Micropalaeontology, 7: 233-240.

Ogden, C.G., and Hedley, R.H., 1980. An Atlas of Freshwater Testate Amoeba. British Museum (Natural History), Oxford University Press.

Patterson, R.T., MacKinnon, K.D., Scott, D.B., and Medioli, F.S. 1985. Arcellaceans (Thecamoebians) in small lakes of New Brunswick and Nova Scotia: modern distribution and Holocene stratigraphic changes. Journal of Foraminiferal Research, 15:114-137.

Patterson, R.T., Barker, T. and Burbidge, S.M. 1996. Arcellaceans (thecamoebians) as proxies of arsenic and mercury contamination in northeastern Ontario lakes. Journal of Foraminiferal Research 26:172-183.

Penard, E. 1890. ftudes sur les Rhizopodes d'eau douce. M moires de la Soci $\mathbf{t}$ de Physique et d'Histoire Naturelle de Gen ve, 31(2), 1-230.

Penard, E. 1899. Les Rhizopodes de faune profonde dans le lac L man. Revue Suisse de Zoologie, 7, 1-142.

Penard, E. 1902. Faune Rhizopodique du Bassin du L man. Henry Kundig, Gen ve.

Penard, E. 1905. Les Sarcodines des grands lacs. Henry Kundig, Gen ve.

Perty, M. 1849. Uber vertikale Verbreitung mikroskopischer Lebensformen. Naturforschende Gesellschaft in Bern Mittheilungen, 153-176.

Reinhardt, E.G., Dalby, A.P., Kumar, Arun, and Patterson, R.T. 1997. In press. Utility of arcellacean phenotypic variants as pollution indicators in mine tailing contaminated lakes near Cobalt, Ontario, Canada.

Micropaleontology 43(3).

Scott, D.B., and Medioli, F.S., 1983. Testate rhizopods in Lake Erie: modern distribution and stratigraphic implications. Journal of Paleontology, 57:809-820.

Wallich, G.C. 1864. On the extent, and some of the principal causes, of structural variation among the difflugian rhizopods: Annals and Magazine of Natural History, series 3, 13:215-245. 


\section{GLOSSARY}

Acuminate - tapering to form a spine.

Agglutination - foreign particles bound together by cement into a test.

Aperture - opening of the test. It is standard procedure to figure the specimens aperture up.

Autogenous - a test secreted by the organism.

Frustule - diatom shell.

Fundus - the end of the test opposite the aperture (also called the aboral end). Idiosomes - agglutinated foreign particles of the test made from other organic material.

Strain - infraspecific morphological variant.

Test - shell, or external hard part, of a protozoan.

Xenogenous test - test composed of agglutinated foreign particles.

Xenosome -agglutinated foreign particles of the test made from mineral grains. 